\title{
O CONCEITO HEGELIANO DE RELIGIÃo
}

\author{
[THE HEGELIAN CONCEPT OF RELIGION]
}

\author{
Marcos Fábio Alexandre Nicolau * \\ Universidade Vale do Acaraú, Brasil
}

\begin{abstract}
Resumo: Nosso texto propõe uma breve exposição sobre a concepção hegeliana de religião presente nas Vorlesungen Über Die Philosophie Der Religion (Lições Sobre a Filosofia da Religião). Compreendendo a religião como uma das formas de autoexpressão do Espírito Absoluto no mundo, Hegel apresenta uma compreensão processual das religiões na história, convergente com sua proposta lógico-dialética do real. Para tal, elencamos passagens chave dessas Lições em sua sistemática formulação do conceito de religião. Por fim, enfatizamos ser o mesmo o resultado das diferentes "representações" da divindade na história e cultura humanas que, ainda que divergentes em suas formas de expressão, trazem como unidade o fato de ser a experiência que cada situação humana, individual ou coletiva, impôs nesse processo de realização do Espírito Absoluto no mundo.
\end{abstract}

Palavras-chave: Espírito Absoluto; Representação; Finito/Infinito
ABSTRACT: Our text proposes a brief exposition on the Hegelian conception of religion present in the Vorlesungen Über Die Philosophie Der Religion (Lessons on the Philosophy of Religion). Understanding religion as one of the forms of self-expression of the Absolute Spirit in the world, Hegel presents a procedural understanding of religions in history, converging with his logical-dialectical proposal of the real. To this end, we list key passages from these Lessons in their systematic formulation of the concept of religion. Finally, we emphasize that it is the same as the result of the different "representations" of divinity in human history and culture that, although divergent in their forms of expression, bring as unity the fact that it is the experience that each human situation, individual or collective, imposed in this process of realization of the Absolute Spirit in the world.

KEYWORDS: Absolute Spirit; Representation; Finite/Infinite

\section{A religião é a segunda configuração do Espírito Absoluto no sistema} hegeliano. Para Hegel, a religião significa a elevação do espírito finito ao infinito, e o caminho, o modo e a realização dessa elevação e de sua coincidência final é o que tratou de mostrar em suas Lições Sobre Filosofia da Religião $(V P h R)^{1}$. Notemos que aqui se trata de filosofia (VIEILLARD-BARON, 2002, p. 60), pois a religião é também uma forma dialética da autorrealização do Espírito Absoluto. No entanto, como bem anunciou em seu Discurso Inaugural da Docência de Filosofia em Berlim, a religião é uma forma que deve ser suprassumida ${ }^{2}$ : anulada e suprimida, pois é insuficiente, logo superada e elevada, mas, por isso mesmo, absorvida e conservada

* Doutor em Educação pela Faculdade de Educação da Universidade Federal do Ceará FACED/UFC. Bolsista de Produtividade em Pesquisa BPI/FUNCAP. Professor Adjunto do Curso de Filosofia e do Mestrado Acadêmico em Filosofia da Universidade Estadual Vale do AcaraúUVA. Coordenador do Laboratório de Estudos Hegelianos - LEH/UVA-CNPq. E-mail: marcosmcj@yahoo.com.br. 
como fundamento na e através da filosofia ${ }^{3}$ :

A filosofia [tem] portanto o mesmo fim e conteúdo que a religião, não só [como] representação, mas como pensar. A figura da religião [é] por isso insatisfatória para a consciência cultivada mais alta - ela tem de querer conhecer, de suprassumir a forma da religião -, mas apenas para justificar o seu conteúdo. (HEGEL, 1990, p. 166)

Nas $V P h R$ consideramos a religião apenas em sua forma dialética, e não em suas outras vertentes possíveis - política, psicológica, sociológica etc. Por isso mesmo, ainda que apresentemos aqui apenas uma visão geral destes escritos, acreditamos que Hegel não pretendeu fazer uma história das religiões, ou seja, uma exposição focada nos contextos e detalhes de cada religião, mas demonstrar o entrelaçamento interno do devir histórico dessas distintas representações (Vorstellung) da divindade. Contudo, para facilitar a compreensão desta linha de interpretação e propor uma visão panorâmica do campo intelectual sobre o que tratam estes escritos de Hegel, adiantaremos aqui um esquema geral dessas lições, agrupando algumas divisões e apresentando a terminologia hegeliana, por vezes esotérica.

Depois de uma longa introdução sobre o conceito, objeto, desenvolvimento, método e temática dos campos conexos da filosofia e da teologia, as $V P h R$ dividem-se, em todas as suas versões $(1821,1824$ e 1827), em três grandes partes. Na primeira, se estuda o conceito de religião, o saber imediato, o sentimento religioso, a representação religiosa, a dialética do finito, a mediação absoluta (é aqui onde Hegel coloca, pela primeira vez, as "provas" da existência de Deus), e, finalmente, a realidade (diríamos externa) da religião, o culto, a religião e a arte (Kunst), e a religião e o Estado (Staat).

A segunda parte trata da religião determinada ou finita, quer dizer, das formas nas quais a religião se manifestou, com duas grandes partes: 1) as religiões da natureza (marcadas especialmente pelos credos orientais, nos quais analisa o estado primitivo, $\mathrm{o}$ paraíso, a queda, a feitiçaria, o culto aos mortos, o Tao, o culto aos gênios, o bramanismo, as religiões do bem e do mal, da luz e das trevas, os simbolismos e a zoolatria). Os graus ascendentes desta religião determinada são denominados por Hegel religiões imediatas: (a) da substancialidade, (b) da subjetividade abstrata e (c) do enigma; e 2) as religiões da individualidade espiritual, tratadas e refletidas aqui sob as formas: (a) da religião do sublime, que seria a judaica, (b) da religião da beleza ou individualidade bela, que seria a grega, e (c) da religião da finalidade imediata e do entendimento finito, expressa especificamente pela romana $(W$, v. 16, p. 86) - na religião do sublime está a interessante reflexão sobre "a aparição da essência" que vem a ser uma descrição fenomenológica do modo dialético de entender a criação como a "posição" do "Outro" de Deus (W, v. 17, p. 54). Posterior a essa reflexão está uma nova elaboração das provas da existência de Deus, de suas "representações" e, por fim, dos temas do trágico, do culto dos enigmas e oráculos, da relação religião e estado, antes de justificar a passagem à terceira parte ( $W$, v. 17, p. 173-182).

A terceira parte se intitula religião consumada ou manifesta, a que propriamente poderíamos considerar a religião em sua forma absoluta. Hegel se refere com essas denominações, como é sabido, ao cristianismo. Depois de precisar a abrangência conceitual desse nível histórico alcançado e tido como determinado, e de analisar a positividade e a espiritualidade da religião absoluta, o filósofo apresenta seu comentário à santíssima trindade (Dreieinigkeit) ${ }^{4}$, no qual delineia três momentos: o momento do Pai, ou o pensamento (Gedanke), o momento do Filho, ou a representação (Vorstellung), e o momento do Espírito, ou o conceito (Begriff) (W, v. 17, p. 221-240). Nessa parte das $V P h R$, o filósofo comenta de forma mais detalhada o conceito cristão de Deus, a partir da representação mítica da queda ou do pecado original, que vincula à reconciliação mediante a encarnação (Menschwerdung) $)^{5}$ de Deus e a presença permanente do mesmo na comunidade do Espírito. Para Lima Vaz, aqui Hegel lança a ideia de que depois do cristianismo, não se pode pensar outra religião, pois essa seria "a religião absoluta porque, apresentando a encarnação, cortou as possibilidades de outra 
mensagem religiosa histórica e se tornou a última mensagem religiosa possível" (LIMA VAZ, 2014, p. 171).

Curiosamente, o momento do Espírito é representado na obra pelo conceito de comunidade (Gemeinde) ( $W$, v. 17, p. 299-344), o que remete à Igreja, embora em nenhum momento desses escritos seja expressa qualquer apologia, seja protestante, seja católica - talvez por puro instinto de preservação ao pensar no que aconteceu com Fichte, em Jena ${ }^{6}$, mas em nossa compreensão justifica-se para suas pretensões não ter isso como questão ${ }^{7}$. Entenda-se que tudo é aqui "hegeliano", ou seja, submetido ao desenvolvimento especulativo de seu sistema filosófico, e por isso, elaborado com vistas a dar uma interpretação mais dialética que hermenêutica da história das religiões. Apresentou, aqui, o projeto anteriormente esboçado em Fé e Saber ${ }^{8}$, a saber, o de

reestabelecer para a filosofia a ideia da absoluta liberdade e, desse modo, o sofrimento absoluto ou a sexta-feira santa especulativa, que foi, além disso, histórica e a partir de cuja rigidez apenas pode e deve ressuscitar a suprema totalidade (HEGEL, 2007, p. 174).

Eis o processo que o absoluto passou até expressar-se como Deus revelado. Nessa via sacra, as últimas estações mantêm e conservam todos os passos e paradas das primeiras; porém, revelam a luz que brotou de todas as traumáticas "aparições" e "oposições" divinas através do mundo9 e da consciência do homem, como salienta Hösle:

A filosofia da religião, entretanto, reconhece que as convicções da religião extraem suas verdades do próprio ato religioso: se os homens não cressem na encarnação de Deus, não seria correto dizer que Deus se fez homem e que o Espírito Santo age no mundo; com efeito, Deus se consuma somente pelo fato de ser sabido como tal. Justamente essa relação ao sujeito é o ponto forte do conceito especulativo de religião em Hegel (HÖSLE, 2007, p. 700).

Também nessa consideração filosófica da religião, na qual o pensamento é simbolizado pelo próprio percurso da história do conceito e da vida mesma de Deus, vislumbramos um vazio melancólico profundo: "O finito, que se exalta ao infinito, é mera identidade abstrata, inerentemente vazia, a forma suprema da mentira, da falsidade e do mal" ( $W$, v. 16, p. 186). Eis o porquê da submissão do homem (finito) à espera e escuta do acontecer histórico para tomar consciência das mesmas. Eis o preço dessa estranha e transparente revelação (infinito). Só mediante ela, pensa Hegel, pode chegar o homem a encontrar o sentido de sua meta: o de ver e sentir unidos o finito e o infinito, o humano e o divino, que é, justamente, o que todos os grandes pensadores dialéticos pretenderam alcançar e ver na divindade, a saber, a identidade na contradição ( $W$, v. 17 , p. 225).

Com a filosofia da religião ${ }^{10}$ chegamos ao penúltimo nível que vai encerrar o círculo de círculos que é o pensamento hegeliano (HEGEL, 1995¹, p. 30). Como observamos, a religião já não é considerada aqui como "positividade" opressora em sua realização histórica e institucionalizada, como ocorreu com sua análise do cristianismo nos Escritos Teológicos de Juventude ${ }^{11}$. Nas $V P h R$ a religião já não engendra "alienação" porque já temos um sistema maduro e elaborado, que sabe como o estranhamento deve converter-se em apropriação. A religião é agora processo de formação e libertação humana, libertação do finito por sua imersão no infinito ou de seu autoconhecimento enquanto absoluto. Não por acaso, defende ser o objeto da religião o mais elevado de todos, ao qual a filosofia não poderia renunciar, como bem expressa Plant:

A filosofia é [...] "Gottes dienst" - culto a Deus. A transcrição da vida e da experiência humanas em conceitos filosóficos, inserida numa explicação total que é Conhecimento Absoluto, é uma transcrição da natureza e da historia de Deus. Ela coloca o conteúdo da religião de maneira nova, de modo que não 
apreendemos as verdades profundas da vida somente por meio de historias e representações, mas também por meio de uma estrutura conceitual que é publicamente acessível a todos e, como um entendimento partilhado da experiência, pode formar a base de uma vida em comum (PLANT, 2000, p. 5253).

$\mathrm{Na}$ perspectiva religiosa hegeliana, a imagem do Absoluto não é mais a de um ideal inalcançável, ou utópico, ou localizado em um inacessível além, senão que brilha na obscuridade do presente temporal como a substância concreta presencialmente atuante. Para o filósofo, não se pode continuar fomentando o falso conflito entre razão e fé, uma verdadeira loucura, um absurdo que ressoava ainda em seu tempo ( $W$, v. 17, p. 349). Dizer que o pensamento traz males à religião ou que a religião será tanto mais sólida quanto mais renuncie a pensar era o discurso a ser combatido, pois isso significaria ignorar o desenvolvimento do Espírito. Lembremos que a religião também configura o conhecimento que o Espírito Absoluto tem de si através da mediação do espírito finito. ( $W$, v. 16, p. 161).

Isso porque, assim como ocorre em suas Lições Sobre Filosofia da História, Hegel parte da hipótese de que o espírito é a realização de seu conceito no devir histórico (HEGEL, 1995², p. 59), identificando esses passos históricos aos passos metodológicos expostos didaticamente na Ciência da Lógica $^{12}$. Dessa forma, a verdadeira revelação não é nada mais que o modo do autodesvelamento histórico e processual de Deus, ou seja, a própria historicização dialética da razão.

Quando Hegel fala do conceito metafísico de Deus, ele tenta nos situar inicialmente na esfera da imediaticidade, na qual Deus é uma unidade absoluta. Mas a imediaticidade do conceito equivale, assim como o conceito puro na esfera da lógica, ao conceito do nada (HEGEL, 2016, p. 84). A unidade de Deus, ao contrário, é a de todos e de cada um na santíssima trindade ( $W$, v. 17, p. 234), o que de algum modo já é vislumbrar a alteridade no conceito. A verdadeira forma da imediaticidade do conceito de religião é a condução espontânea para a mediação, que é o que configura a verdadeira religião.

No primeiro momento abstrato, Deus seria algo indeterminado, mas o Deus real não pode ser uma "identidade imediata", sem mediação. Deus como o "imediato de si mesmo" ( $W$, v. 17, p. 216) é apenas o ponto de partida de nosso excurso didático para a apreensão de seu conceito. Pois essa falta de conteúdo não corresponde em nada ao conceito vivo que Deus é, nem ao conceito de vida que dele possuímos em nosso pensamento. Na realidade, o próprio conceito de Deus deve trazer consigo a mediação, sob o risco de não possuir determinação (Bestimmung). Eis a raiz e o caminho para as provas de sua existência. O conceito abstrato e metafísico de Deus é totalmente simples, ou melhor, é a própria simplicidade. Mas a nossa representação mais profunda de Deus não pode acomodar uma mera determinidade (Bestimmtheit). Isso é o suficiente para justificar nosso necessário mergulho na complexidade que é seu conceito: uma determinação conceitual não é algo que está em si em repouso, mas está em movimento, é essencialmente ação ou efetividade. Portanto, todo conceito já é mediação; o pensamento já é essa mediação, enquanto inquieto e ativo, pois se o pensamento é determinado, já contém a própria mediação.

Sabemos que Hegel assume a famosa sentença espinosana, que reza: Omnis determinatio est negatio (HEGEL, 2016, p. 117) ${ }^{13}$, compreendendo que esse processo de mediação e determinação é condição sem a qual a análise do conceito seria impossível. Toda determinação traz dentro de si um ato de negação, um confronto com aquilo que ela não é, ou seja, uma mediação na qual se distingue de tudo o mais. Temos aqui o princípio sob o qual Hegel irá justificar sua análise da diversidade das aparições ou das "representações" de Deus na história, que irão moldar as várias formas de religião - cada uma delas configura uma contribuição na determinação do conceito de Deus. A consumação da religião será refletida na forma final dessas "representações" e Hegel consolidará o cristianismo como a representação mais alta, por ser a 
manifestação realizada exclusivamente nos mistérios da santíssima trindade e da encarnação ( $W$, v. 17, p. 351). O fenômeno da "finitização" de Deus foi assumido pelo filósofo como o evento mais relevante da história das religiões ( $W$, v. 17, p. 12).

Para ele, o verdadeiro Deus é aquele que assume a mediação, ou seja, que é finitizado, fenomenalizado, determinado através do processo histórico. Por isso, não hesita em dizer que a encarnação é o "momento essencial" da religião ( $W$, v. 16, p. 75), no qual toda predicação divina deve encontrar fundamento. Porque essa finitização do infinito implica uma infinitização do finito, uma elevação do fïnito para a divindade através da mediação do infinito nele. O finito torna-se divino, alcançando assim a negação da finitude. Isso é o que dá sentido à sua concepção dialética do surgimento histórico das religiões.

Ao assumir a dimensão especulativa que a determinação traz em si, que no caso dessa dimensão religiosa de manifestação do Absoluto implica nas consequências de admitirmos Deus enquanto criador, Hegel está apresentando uma verdade profunda e uma atribuição verdadeiramente clara de seu conceito, pois ao vislumbrarmos que antes da criação não havia nada, temos que admitir que Deus determina-se ao defrontar-se com o outro de si, ou seja, o mundo criado é condição da determinação divina.

Deus cria o mundo a partir do nada; isto é, sem o mundo não há nada exterior, porque é a própria exterioridade. Somente Deus é; mas Deus é somente através de sua mediação consigo mesmo; ele quer o finito; ele próprio o coloca como um outro e assim se torna outro de si, um finito, pois ele tem outro oposto a si mesmo. Mas esta alteridade é a contradição de si consigo mesmo. Ele é assim o finito em relação ao finito; mas a verdade é que esse finito é apenas uma aparência, uma forma fenomenal na qual Ele próprio se tem. A criação é a atividade; nela reside a diferença, mais uma vez, o momento do finito. Mas essa existência separada do finito deve também suprassumir-se novamente, porque é Deus; é o seu outro e ainda está determinada como outro de Deus. Ela é o outro e o não outro; ela se dissolve; ela não é Ele mesmo, mas um outro; ele se arruína. Mas por isso a alteridade desapareceu completamente em Deus, e Deus reconhece-se nela, através dela recebe a si mesmo como resultado de seu próprio ato $(W$, v. 16, p. 191).

Embora Deus e mundo sejam dois, e só Deus efetivamente seja, a questão aqui é que algo só pode ser na mediação, e no caso de Deus, na mediação de si consigo mesmo - sendo o mundo/cosmo sua exteriorização. O ato criador inaugura a diferença, a multiplicidade, a contingência, a finitude em Deus, que passa a ser nesse movimento e somente através dele concebido, pois "Deus sem o mundo não seria Deus" ( $W$, v. 16, p. 192). Esta é a forma da identidade na diferença que o verdadeiro Deus nos revela ${ }^{14}$.

A religião deve levar o espírito a ter consciência de sua essência. Depois dessa divisão divina, dessa separação, a união, a síntese deve seguir logicamente (cf. TAYLOR, 2014, p. 520). E este é o objetivo do âmbito religioso: a elevação do espírito finito ao infinito. Essa elevação é realizada pela negação da finitude. É desse modo que a consciência religiosa consiste no sujeito finito tendo sua essência como seu objeto. A subjetividade finita é em si um dos momentos da subjetividade infinita. A unidade de ambos é o conceito de religião. Somente a partir dessas suposições é possível dar sentido e compreensão ao que Hegel chama de "provas" da existência de Deus $(W, \mathrm{v}$. 17 , p. $347 \mathrm{~s})$.

Como ponto de partida, argumenta que o finito pressupõe o infinito, compreendendo que o pensamento deve assumir a unidade de sua identidade e sua diferença. Essa unidade é tanto a mediação quanto a pressuposição do infinito através do finito. O ser somente é enquanto ser-para-o-outro - essa é uma proposição fundamental, pois tudo depende ou nasce dessa conexão ${ }^{15}$. "Provar", portanto, deve consistir apenas em descobrir, revelar ou esclarecer para a consciência a relação ontológica, ou em termos kantianos, "transcendental"16, da presença do infinito no finito e vice-versa. É, portanto, necessário tornar explícito para a consciência finita algo 
que lhe é implícito, ainda que efetivo: sua infinitude. Mas isso precisa ser entendido em dois níveis diferentes: o individual (subjetivo) e o histórico (objetivo). O histórico tem que enriquecer o indivíduo e aperfeiçoá-lo. Como apresentado na Fenomenologia do Espírito, o indivíduo, ao alcançar a autoconsciência, está apto ao saber absoluto (das absolute Wissen), está apto ao saber conceituante (das begreifende Wissen), capaz de

146 apreender o conceito de Deus. O homem, a partir de sua finitude, pode agora desvelar a si mesmo em sua relação com Deus, ou seja, com a infinitude. Em linguagem hegeliana, é para-si ao ser para-o-outro, ou seja, conhece a si mesmo enquanto é mediação entre Deus e mundo. Nos dois sentidos, podemos falar de uma revelação ontológica da verdade de Deus, pois, como fora anunciado nessa mesma obra: "Sobre o Absoluto, deve-se dizer que é essencialmente resultado, que só no fim é o que é na verdade" (HEGEL, 2002, p. 36). No homem esse resultado é consequência de sua própria eticidade, de sua cultura, de sua dialética histórica. Dialética essa que deve efetivar essa manifestação objetiva de Deus no mundo, a partir da mediação interna do espírito infinito com a finitude humana.

Essa dialética do Espírito Absoluto realizada no tempo é a história natural e cultural. Em inúmeras passagens de seu sistema, Hegel elucidou a história como sendo a manifestação e efetivação da essência do Espírito, o que passa pela revelação interior de Deus no espírito do homem. Esse movimento dialético ocorre no devir do contingente para o necessário, do finito para o infinito. O homem "representa" o conceito de Deus a partir das condições culturais e ideológicas que sua temporalidade e espacialidade lhe impuseram. Assim, Deus foi representado nas formas dos deuses históricos das diferentes religiões, seguindo, na visão do filósofo, um caminho ascético em direção à religião consumada, manifesta e absoluta. Tal processo configura uma ontologia e uma epistemologia do divino, uma lógica transcendental da história a partir das expressões religiosas. O que pode parecer uma mera procissão de divindades, cultos, estatutos morais e práticas ascéticas, na verdade é um processo lógico de automanifestação de Deus realizado pelo homem, ainda que quase inconscientemente. Eis a motivação hegeliana ao se embrenhar no percurso histórico das religiões.

Deus se revela ao homem na religião, e ele revela assim homem a si mesmo. A essência da religião é ser testemunho ou manifestação de Deus; a consciência religiosa não é mais a visada por uma essência absoluta ou Deus, mas o testemunho de Deus. As lições de filosofia da religião dirão que, na religião, o espírito rende testemunho a si mesmo. (VIEILLARD-BARON, 2002, p. 53)

Compreender o mistério dessa relação significa compreender a nós mesmos e, por extensão, a própria essência de Deus. Nesse momento, as $V P h R$ configuram tanto uma antropologia quanto uma teodiceia, pois em cada realização social, cultural e histórica, Deus efetiva-se e conhece-se no homem: “O ser humano é o veículo de Deus para consciência de si” (TAYLOR, 2014, p. 519). Como dito acima, esses escritos possuem esse caráter antropológico porque o homem define seus deuses enquanto expressões de sua existência temporal, de seus pensamentos e sentimentos, de seus medos e suas ansiedades, de suas ilusões e anseios por felicidade. É por isso que as religiões nos oferecem diferentes "representações" da divindade, convergentes em alguns pontos de expressão e divergentes em outros, pois concordam com a experiência que cada situação humana, individual ou coletiva, impôs. Ao mesmo tempo em que isso pode ser tido como ponto de partida das religiões, configura sua limitação, pois não proporciona apreender a dialética do finito e do infinito, do contingente e do absoluto. Por isso, sua apreensão consciente e completa somente seria possível através da filosofia - não percamos de vista que, mais do que uma história das religiões, Hegel arquitetou aqui uma filosofia da religião: uma narrativa didática da realização "representativa" do conceito de Deus na história (HEGEL, 1995', p. 344-345).

Como sempre, "a coruja de Minerva somente começa seu voo com a irrupção do crepúsculo" (HEGEL, 2010, p. 44), voo que aqui é representado pelo percurso histórico das religiões: "A religião é um produto do espírito divino, e não uma invenção humana, 
mas a obra do espírito divino expressando-se nela" ( $W$, v. 16, p. 40). E enfatiza em suas Lições sobre Filosofia da História:

Ela [a religião] é o primeiro modo da autoconsciência, a consciência espiritual do espírito do próprio povo, do espírito universal, em si e para si existente, segundo a determinação que ele a si fornece no espírito de um povo; a consciência do que é verdadeiro, na sua determinação mais pura e mais íntegra. O que ademais se determina como verdadeiro vale para mim, porquanto é conforme ao seu princípio na religião. A religião, a representação de Deus, constitui, portanto, o limite universal, o fundamento do povo. A religião é o lugar onde um povo proporciona a si mesmo a definição do que ele tem por verdadeiro (HEGEL, $1995^{2}$, p. 125).

Nas $V P h R$ o filósofo lamenta verificar que essa relação necessária foi intelectualmente quebrada e esquecida, pois a modernidade

converteu Deus em um fantasma infinito, que está longe de nossa consciência, e ao mesmo tempo reduziu o conhecimento humano a um vão fantasma da finitude, um esquema e cumprimento da aparência. ( $W$, v. 16, p. 43 )

Em resumo e síntese: embora a iniciativa venha da "razão divina" - base inexorável e sempre ponto de partida -, conta com o necessário ato livre da consciência subjetiva, "a representação que o homem faz de Deus corresponde àquela que o homem faz de si mesmo e de sua liberdade" ( $W$, v. 16, p. 83).

\section{REFERÊNCIAS}

BAVARESCO, A. A estrutura processual da finitude na Lógica hegeliana. In: BAVARESCO, A.; FERREIRO, H; HOFFMANN, T. S. Os aportes do itinerário intelectual de Kant a Hegel. Porto Alegre: Editora Fi/EDIPUCRS, pp. 199-218, 2014.

BECKENKAMP, J. O Jovem Hegel: formação de um sistema pós-kantiano. São Paulo: Edições Loyola, 2009.

BOURGEOIS, B. O Pensamento Politico de Hegel. São Leopoldo: Unisinos, 2000.

BORGES, M. L. A Atualidade de Hegel. Florianopólis: Editora UFSC, 2009

DICKEY, L. Hegel, a religião e a filosofia. In: BEISER, F. C. (Org.). Hegel. São Paulo: Ideias \& Letras, pp. 353-406, 2014.

GAINZA, M. de. Espinosa: Uma filosofia materialista do infinito positivo. São Paulo: Edusp, 2011.

GUINZO, A. En torno a la filosofía de la religión em Hegel. In: HEGEL, G. W. F. El concepto de religión. Mexico: Fondo de Cultura econômica, 1981.

HEGEL, G. W. F. Vorlesungen über die Philosophie der Religion, I-II [Bd. 16-17]. In: Werke: [in 20 Bänden]. Auf der Grundlage der Werke von 1832-1845 neu edierte Ausgab. Eds. Eva Moldenhauer e Karl Markus Michel. Frankfurt am Main: Suhrkamp, 1986.

HEGEL, G. W. F. Discurso inaugural da docência de filosofia em Berlim. In: HEGEL, G. W. F. Prefácios. Tradução de Manuel J. Carmo Ferreira. Lisboa: Imprensa Nacional/Casa da Moeda, 1990.

HEGEL, G. W. F. Enciclopédia das Ciências Filosóficas - Filosofia do Espírito. Tradução Paulo Menezes, com a colaboração de José Machado. São Paulo: Edições Loyola, $1995^{1}$.

HEGEL, G. W. F. A Razão na História: introdução à filosofia da história universal. Trad. de Arthur Morão. Lisboa: Edições 70, $1995^{2}$.

HEGEL, G. W. F. Fenomenologia do Espírito. Tradução de Paulo Menezes com colaboração de Karl-Heinz Efken e José Nogueira Machado, SJ. Petrópolis: Vozes, 2002.

HEGEL, G. W. F. Fé e Saber. São Paulo: Hedra, 2007.

HEGEL, G. W. F. Filosofia do Direito. Tradução de Paulo Meneses [et al]. São Leopoldo: Unisinos, 2010. 
HEGEL, G. W. F. Ciência da Lógica - 1: A doutrina do Ser. Tradução de Christian G. Iber, Marlorem L. Miranda e Federico Orsini. Petrópolis/Bragança Paulista: Editora Vozes/Editora Universitária São Francisco, 2016.

HÖSLE, V. O Sistema de Hegel - o idealismo da subjetividade e o problema da intersubjetividade. Tradução de Antonio Celiomar Pinto e Lima. São Paulo: Edições

$148 \quad$ Loyola, 2007.

LEBRUN, G. A Paciência do Conceito: ensaio sobre o discurso hegeliano. São Paulo: EdUnesp, 2006.

LIMA VAZ, H. C. de. A Formação do Pensamento de Hegel. São Paulo: Loyola, 2014.

LÖWITH, K. De Hegel à Nietzsche. Paris: Gallimard, 2003.

MACHEREY, P. Hegel ou Spinoza. Paris: La découverte, 1990.

NICOLAU, M. F. A. O Ser Como Ciência. A Ciência da Lógica de Hegel. Munich: Grin Verlag, 2008

OLIVEIRA, M. A. Para Além da Fragmentação: pressupostos e objeções da racionalidade dialética contemporanea. São Paulo : Edições Loyola, 2002.

OLIVEIRA, M. A. Hegel, síntese entre a racionalidade antiga e moderna?. In: CHAGAS, E. F.; UTZ, K.; OLIVEIRA, J. W. J. Comemoração aos 200 Anos da "Fenomenologia do Espirito" de Hegel. Fortaleza: Edições UFC, pp. 39-63, 2007.

PERTILLE, J. P. Aufhebung, meta-categoria da lógica hegeliana, para uma plausível apreensão da lógica da realidade. In: BAVARESCO, Agemir; LIMA, Francisco Jozivan Guedes de (Orgs.). Direito e Justiça: Festschrift em homenagem a Thadeu Weber. Porto Alegre: Editora Fi, pp. 365-380, 2016.

PLANT, R. Hegel: sobre religião e filosofia. São Paulo: EdUnesp, 2000.

SILVA, F. J. A. Trindade na "Fenomenologia do Espírito". In: CHAGAS, E. F.; UTZ, K.; OLIVEIRA, J. W. J. Comemoração aos 200 Anos da "Fenomenologia do Espírito" de Hegel. Fortaleza: Edições UFC, pp. 399-407, 2007.

TAYLOR, C. Hegel - Sistema, Método e Estrutura. São Paulo: É Realizações, 2014.

UTTEICH, L. C. Johann Gottlieb Fichte: aspectos biográficos do filósofo da Egoidade Absoluta. In: Tempo da Ciência, v. 16, n. 32, pp. 111-122, 2009.

VIEILLARD-BARON, J.-L. Comunidade ética e comunidade religiosa na Fenomenologia do Espírito, de Hegel. In: Revista Filosofia Política, série III, n. 3, pp. 48-62, 2002.

\section{Notas}

1 No decorrer do artigo as citações da $V P h R$ serão abreviadas por $W$, seguidas pelo número do volume e da página, e referem-se aos volume 16 e 17 da edição de 1832-1845, organizadas por Eva Moldenhauer e Karl Markus Michel, publicadas pela Suhrkamp Verlag (vide referências).

2 Para tradução da Aufhebung hegeliana assumimos a solução de Meneses, assim descrita na recente tradução da $W d L$ : "A fim de dispor de um verbo que pudesse expressar as três nuanças de aufheben (isto é, negar, conservar, elevar) resolvemos seguir a solução já oferecida por Paulo Meneses: o neologismo suprassumir. Este verbo foi cunhado justamente para significar o caráter progressivo de uma ação que, ao mesmo tempo, realiza um suprimir (sumir), um conservar (assumir) e um elevar (supra+assumir). A nosso ver, as outras opções disponíveis estão afetas por unilateralidades ou evidentes diferenças semânticas, que podem ser fonte de uma compreensão desviante do texto hegeliano, como por exemplo, "superar", "remover" ou "suspender"." (HEGEL, 2016, p. 20 [NT]). Ainda sobre a importância da Aufhebung como uma meta-categoria do sistema hegeliano: "O tema é acerca do estatuto da suprassunção, se ela pode ser reconhecida não como uma categoria lógica assim como o ser, o nada e o vir-a-ser, e as demais categorias lógicas que as sucedem até a ideia absoluta, mas mais propriamente como uma metacategoria da lógica hegeliana, isto é, como uma determinação que opera sobre as determinações, e que assim se situa ao nível dos fundamentos do sistema, em outras palavras, Aufhebung não como uma simples Bestimmung, mas como uma 
Grundbestimmung." (PERTILLE, 2016, p. 370).

3 A filosofia pode ser compreendida em Hegel como a continuidade da religião, pois configuraria um culto perpétuo: "Porém, se concebermos o papel do culto como o de trazer os seres humanos de volta de sua subjetividade finita para a unidade com o universal, então ele não se diferencia basicamente das instituições que vimos sob o espírito objetivo (...) Hegel prossegue e acrescenta no parágrafo seguinte: "Nesse tocante, [...] a filosofia é um culto perpétuo" (BRel, p. 236)." (TAYLOR, 2014, p. 522).

4 Sobre a perspectiva hegeliana da santíssima trindade, Silva esclarece: "Em Hegel, a discussão do tema da Trindade parte da perspectiva fenomenológica, na Fenomenologia do Espírito, e desemboca no fim de seu sistema nas Lições Sobre Filosofia da Religião (1821), numa consideração metafísica e especulativa. A consideração fenomenológica, faz-se necessário dizer, parte do ponto de vista da experiência que a Consciência faz de si mesma, e não de uma perspectiva da realidade histórica da religião enquanto tal ou de sua dogmática. Embora tenha relação com esta, ela é compreendida a partir das figuras do Espírito, ou seja, da Consciência, da Autoconsciência, da Razão e do Espírito.” (SILVA, 2007, p. 400).

5 "A Encarnação, por mais grosseiro que tenha sido o modo de interpretá-la, esboçava uma significação do divino que a Grécia não havia entrevisto. Ousar dizer "Ele era Deus e também aquele homem" é deixar adivinhar que o Finito não é tão opaco que não possa acolher o Infinito, e que é possível outra relação entre o homem e Deus que não a contemplação, relação imaginativa, que os deixa cada qual em seu lugar. Enquanto os textos de juventude atribuem à imaginação o poder de conciliar sujeito e objeto, natureza e liberdade, agora, Hegel insiste na fragilidade desse equilíbrio: na conciliação imaginativa, o homem permanece espectador de uma eternidade separada dele, perante uma objetividade que as imagens dos deuses simbolizam. Hegel escreveu outrora: "O homem pode ligar-se ao contingente, e deve ligar a algo de contingente, o imutável e o sagrado" (Nöhl, 143). Nessa "ligação", porém, a união da significação sagrada e do suporte visível permanece exterior. Ora, é essa exterioridade que o cristianismo apaga." (LEBRUN, 2006, p. 33).

6 J. G. Fichte buscou em suas obras legitimar o caráter laico da razão, na tentativa de substituir a moral religiosa tradicional por uma moral laica e puramente racional, sendo seus escritos considerados uma ameaça ao status quo, o que lhe impôs aberta oposição, cuja defesa custar-lhe-á a cátedra em Jena. E, em consequência de uma admoestação, Fichte remete uma carta ao ministério, na qual destitui-se de seu cargo. (cf. UTTEICH, 2009). Mas isso não fora uma exclusividade fichteana, pois até a filosofia especulativa hegeliana fora perseguida pela acusação de ateísmo até a morte do filósofo, em 1831 (cf. DICKEY, 2014, p. 372).

7 Pois como bem afirma Bourgeois: "E por essa objetividade pensante que o Estado se distingue não apenas das esferas anteriores, mas também da esfera posterior do Espírito Absoluto e, particularmente, de seu momento central, a religião. Nos Princípios da Filosofia do Direito, Hegel recusa ver na religião, frequentemente tomada na desrazão supersticiosa e jamais propriamente pensante, a base da objetivação do pensamento racional, isto é, do Estado. Certamente, a religião em sua verdade, sendo a apreensão comum do Absoluto, e a garantia absoluta do Universal estatal, e o Estado deve exigir de seus cidadãos que se vinculem a uma comunidade religiosa qualquer, que ele protege em troca, ao mesmo tempo em que vigia seu agir exterior, mas Hegel considera então a separação da Igreja e do Estado como racional; ele afirma que a separação e a multiplicação das igrejas permitiram a separação da Igreja e do Estado para o maior bem tanto da Igreja como do Estado, e, para ele, o Estado deve rejeitar resolutamente todo clericalismo teórico e prático." (BOURGEOIS, 2000, p. 128).

8 "No tratado sobre "Fé e Saber" (1802), Hegel seguiu o mesmo sentido dos Escritos Teológicos de Juventude. Buscou superar, opondo-se a Kant, Jacobi e Fichte, o contraste "positivo" entre a fé e o saber, mediante uma unidade mais alta e ao mesmo tempo mais originária. Com efeito, se não sabemos nada de Deus e só podemos crer nele; se a razão não é capaz de "conhecer a Deus", então não haverá nem autentica fé nem verdadeiro saber, senão a 
morta síntese, própria da Filosofia da Iluminista, entre a fé e o saber.” (LÖWITH, 2003, p. 391).

9 “[...] o mundo já não é mais pura participação de um Absoluto transcendente, senão que $<$ forma parte $>,<$ pertence $>$ ao Absoluto mesmo que deixa de ser algo <separado $>$. O esforço constante de Hegel vai consistir [...] em encontrar o Absoluto, não mais no além do mundo, senão presente nele; no mundo no qual os homens sofrem e trabalham, duvidam e esperam, destroem e criam, morrem e creem.” (GUINZO, 1981, p. 44).

10 Assumimos juntamente com Vieillard-Baron que: "O modo como Hegel compreende o lugar da filosofia da religião é igualmente essencial para nós. Com efeito, a religião é aquilo que se aproxima mais da filosofia. A filosofia da religião é assim privilegiada. Entretanto, ela não é a pura metafísica, ou a ciência da ideia em si e para si mesma. A história das religiões depende do empirismo puro. A filosofia da religião depende da filosofia do espírito do qual ela é a realização com a filosofia da arte e a historia da filosofia. Estas disciplinas não tem nenhum sentido sem a dimensão especulativa da filosofia pura. Mas, ao mesmo tempo, a filosofia da religião supõe o duplo movimento pelo qual o absoluto se dá na diversidade das religiões, e pelo qual a consciência filosofante eleva esta diversidade ao nível do puro Conceito." (VIEILLARD-BARON, 2002, p. 60).

11 Cabem aqui os esclarecimentos de Beckenkamp sobre este período kantiano de Hegel: "Como visto, Hegel chega, no último ano, em Berna, a descrever a positividade de uma religião como resultado de uma reflexão objetivante, na qual o sujeito racional reflete as consequências da impotência de sua própria razão em um objeto estranho ou exterior a ele mesmo, a cuja legislação caberia, então, submeter-se incondicionalmente (cf. GW 1, 356-357). Em Berna, Hegel chega a essa conclusão no âmbito de seus estudos sobre positividade da religião cristã, revelando um cristianismo dogmático e positivo em que finalmente valem tão somente leis heterônomas a ser seguidas por provirem da vontade de um Deus transcendente." (BECKENKAMP, 2009, p. 133).

12 Como bem afirma Borges: "Hegel divide os espíritos dos povos em quatro grandes impérios: o império oriental, o impero grego, o império romano e o império germânico. A divisão das religiões segue, por sua vez, as divisões da Ciência da Lógica; temos as religiões do ser, da essência e do conceito. O desenvolvimento das religiões vai da mais natural até a mais conceitual e acompanha o desenvolvimento dos impérios" (BORGES, 2009, p. 116).

13 Tradução: "toda determinação é negação". Sobre a interpretação hegeliana da expressão espinosana e sua repercussão, cf. MACHEREY, 1990; GAINZA, 2011.

14 Assim como descrito na Ciência da Lógica, temos aqui uma conversão da prova cosmológica da existência de Deus em uma prova apagógica, na qual o ser de Deus não é derivado da pressuposição do mundo, mas de sua autocontradição interna, como bem descreveu Oliveira: "Na realidade, para Hegel, a estrutura da prova é outra, pois o contingente é contraditório por não poder conservar-se fora do Absoluto; seu ser é, ao mesmo tempo, o ser do outro, ou seja, do ser absolutamente necessário. $\mathrm{O}$ argumento deve, então, ser transformado de tal modo que o momento da negação, que falta na forma tradicional, seja expressamente posto: o finito é nada fora do Absoluto, mas somente seu momento. $\mathrm{O}$ sentido da elevação do espírito consiste justamente nisso: atribuir ser ao mundo, mas não o ser verdadeiro. Somente Deus é o ser verdadeiro. Nessa perspectiva, o sentido da prova é a superação da mediação, pois aquilo por meio de que Deus poderia parecer mediado, o mundo, é declarado nada, de tal modo que o caráter "nádico" do ser do mundo pode constituir o caminho da elevação" (OLIVEIRA, 2002, p. 223).

15 Discutimos o estatuto da dialética finito-infinito na proposta hegeliana de forma mais profunda em um estudo anterior (cf. NICOLAU, 2008), no entanto, recomendamos o sintético e instigante texto de Bavaresco (2014), exposto no I Congresso Germano-Latinoamericano Sobre a Filosofía de Hegel, ocorrido na Pontificia Universidad Católica Argentina, para uma melhor apreensão desse momento crucial da filosofia hegeliana.

16 "Transcendental significa, então, em Kant, segundo Hegel, um termo que contém a explicitação da tarefa específica da fillosofia: demonstrar tais determinações no pensamento subjetivo" (OLIVEIRA, 2007, p. 50). 